\title{
Automated static image analysis as a novel tool in describing the physical properties of dietary fiber
}

\author{
Marcin Andrzej KUREK ${ }^{1 *}$, Monika PIWIŃSKA ${ }^{1}$, Jarosław WYRWISZ1, Agnieszka WIERZBICKA ${ }^{1}$
}

\begin{abstract}
The growing interest in the usage of dietary fiber in food has caused the need to provide precise tools for describing its physical properties. This research examined two dietary fibers from oats and beets, respectively, in variable particle sizes. The application of automated static image analysis for describing the hydration properties and particle size distribution of dietary fiber was analyzed. Conventional tests for water holding capacity (WHC) were conducted. The particles were measured at two points: dry and after water soaking. The most significant water holding capacity ( $7.00 \mathrm{~g}$ water/g solid) was achieved by the smaller sized oat fiber. Conversely, the water holding capacity was highest ( $4.20 \mathrm{~g}$ water $/ \mathrm{g}$ solid) in larger sized beet fiber. There was evidence for water absorption increasing with a decrease in particle size in regards to the same fiber source. Very strong correlations were drawn between particle shape parameters, such as fiber length, straightness, width and hydration properties measured conventionally. The regression analysis provided the opportunity to estimate whether the automated static image analysis method could be an efficient tool in describing the hydration properties of dietary fiber. The application of the method was validated using mathematical model which was verified in comparison to conventional WHC measurement results.
\end{abstract}

Keywords: dietary fiber; particle size; hydration properties; automated static image analysis.

Practical Application: Automated static image analysis could measure precisely the dietary fiber in dry and wet environment which could be a valuable tool for describing the water-holding properties of dietary fiber.

\section{Introduction}

Dietary fiber performs many significant physiological and metabolic functions in the human organism, such as increased intestinal peristalsis, binding of cholesterol, and biliary acids (Cloetens et al., 2012). Thus, there is a growing interest in enriching food with dietary fiber in order to create a new functional food option (Melanson et al., 2006; Ozen et al., 2012)

Generally, supplementary dietary fiber occurs mainly in a form of powder. Enriching food with this substance is mainly accomplished through creating a fiber suspension in water, alcohol or oil. This is crucial, not only from technological point of view, but also from the point of view of consumer acceptance (Zhu et al., 2010).

In case of fiber suspensions created in water, important factors that characterize individual types of fiber are water holding capacity (WHC), swelling capacity, and water retention capacity (WRC). There are few methods used to measure these properties, however, for many sources, the different circumstances in which measurements were conducted (Vissotto et al., 2014), have resulted in a comparison of the obtained results being impossible.

During contact with water, soluble fractions of fiber are dissolved, whereas insoluble fractions absorb water through the cell walls, leading to an increase in the size of the fiber particle
(Autio et al., 2001). Aside from composition, ion form, $\mathrm{pH}$, temperature, and ion power, the size of fiber particles in their non-hydrated state is one of the factors strongly influencing hydration properties (Elleuch et al., 2011).

The main method for measuring dietary fiber particles is a method based on laser diffraction (Zhu et al., 2010). However, this method may carry a noticeable measuring error. The method of particle measurement through laser diffraction involves the need to put particles into motion, in which case movement in certain surroundings (e.g. in water) causes laser beam dispersion. Furthermore, there are many cases, where laser diffraction is not a proper tool for measurement of dietary fiber, since it is typically for use with particles of oval shape (Ma et al., 2000). Automated static image analysis allows learning about not just the size, but also the shape of particles, which is a crucial aspect in measuring fibers of oblong shape. Moreover, proper equipment provides the exact measurement of hydrated particles (Noort et al., 2010). There is no option to measure the WHC using the laser diffraction. However, there is a constant need of researchers to examine this parameter of dietary fiber using fast and general method.

Thus, this paper is to examine the effect of particle size and shape on the water holding capacity of dietary fiber, using automated static image analysis, which will make it possible 
to investigate the water absorbing abilities of individual fiber particles using simple-to-use mathematical models

\section{Materials and methods}

\subsection{Dietary fibers}

The dietary fibers were supplied by Microstructure (Microstructure, Poland). In this research, oat and beet fiber were used. Oat fiber was purchased in two different levels of fineness (D40 and D75 - based on the particle size in $\mu \mathrm{m}$ ). Beet fiber underwent fragmentation on a laboratory scale, using an ultra-centrifugal grinder with a sieve with $0.5 \mathrm{~mm}$ diameter holes (Retsch, ZM 200, Germany). Before milling, the beet fiber is classified as D180 and after milling as D250 - based on the particle size in $\mu \mathrm{m}$.

\subsection{Hydration properties}

In order to examine the water holding properties of fiber, a modified method by Rosell et al. (2009) was used. Water absorption research was carried out in the following way. 1 gram of fiber was flooded in $20 \mathrm{~mL}$ of distilled water and put away for $16 \mathrm{~h}$. After $16 \mathrm{~h}$, the suspension was soaked in a weighed beaker and set aside for 10 minutes in order to drip drain, after which the beaker with water was weighed. The result was presented as a quantity of absorbed water per 1 gram of dry fiber.

\subsection{Particle size and shape measurement}

Measurement of particles size was carried out using the microscope provided with automated static image analysis (Morphologi G3S, Malvern, England). Dry particles underwent dispersion using a sample dispersion unit for a regular arrangement of particles on a microscopic slide, and for breaking up agglomerates or fiber alignment in fiber preparations.

Measurement of particles aimed at reflecting the abilities to absorb water was carried out by allowing the fiber sample preparation to drip drain for $2 \mathrm{~h}$ and then, after mixing the suspension, collecting $5 \mathrm{~mL}$ by syringe and placing it on the wet cell. The early-step measurement yielded the observation that particle size does not change after two hours of soaking.

For the purpose of comparing analysis settings, a z-stacking option was chosen to provide particle measurement in a up and down orientation. The obtained results were divided into two groups - size and shape values. The size values were Diameter D [3.2] $(\mu \mathrm{m})$, Diameter D [4.3] $(\mu \mathrm{m})$, Diameter D [v, 0.1] $(\mu \mathrm{m})$, Diameter D [v, 0.5] $(\mu \mathrm{m})$, and Diameter D [v, 0.9] $(\mu \mathrm{m})$, corresponding to maximum particle diameters of $10 \%, 50 \%$, and $90 \%$. The shape values were circularity, elongation, fiber straightness, total fiber length $(\mu \mathrm{m})$, and fiber width $(\mu \mathrm{m})$.

\subsection{Modeling and verification}

The modeling part was done using central composite model (Design Expert 9.0, Tulsa, USA) to establish a formula by which the WHC could be calculated without a need to use the conventional method (Kurek et al., 2015). The model used six independent variables (diameter D [4.3] $(\mu \mathrm{m})$; circularity, elongation, fiber straightness, total fiber length $(\mu \mathrm{m})$, and fiber width $(\mu \mathrm{m})$ of which function was WHC. After we constructed the matrix of results the best performing model was chosen (linear one). Then we made a verification step when we measured the oat and beet fiber other that used in Material part employing. automated static image analysis. Pararelly, we made a WHC measurement. Next, we calculate the estimated WHC for each of these fibers and checked if they differed significantly from the WHC measured conventionally.

\subsection{Statistical analysis}

The results were elaborated on the basis of univariate analysis of variance to depict statistical differences. In order to set regression patterns, regression analysis was applied, whereas relations between values were determined using a correlation matrix. All analyses were conducted using Statistical 10 for Windows.

\section{Results and discussion}

\subsection{Water holding capacity (WHC) of dietary fibers}

Water absorption (WHC) of dietary fiber presented in Figure 1.

Research on the hydration properties of different dietary fiber preparations show that these properties differ significantly depending on fiber origin and particle size associated with the cereal fibers. Fibers derived from grains (oat fiber) have higher abilities to hold water than fibers derived from vegetables (beet fiber). Fibers typically bind water. Depending on their size, water is either absorbed directly or adsorbed via capillary forces (Rosell et al., 2009). It is commonly known that with decreasing particle size, the water binding capacity of fibers decreases (Ahmed et al., 2015), which is also the case in this study.

The obtained values are confirmed in the literature, since research by Huang et al. (2010) showed the water holding capacity of oat fiber to be at a level of $6.0 \mathrm{~g} / \mathrm{g}$. However, closely examined oat fiber revealed a water holding capacity of $3.5 \mathrm{~g} / \mathrm{g}$. Similar results were collected by Rosell et al. (2009) who proved that oat and wheat fiber reveal water holding capacities of, 6.49 and $6.89 \mathrm{~g} / \mathrm{g}$, respectively. The results are convergent with obtained values.

There is very little information about the properties of beet fiber. One available piece of relevant research was carried out

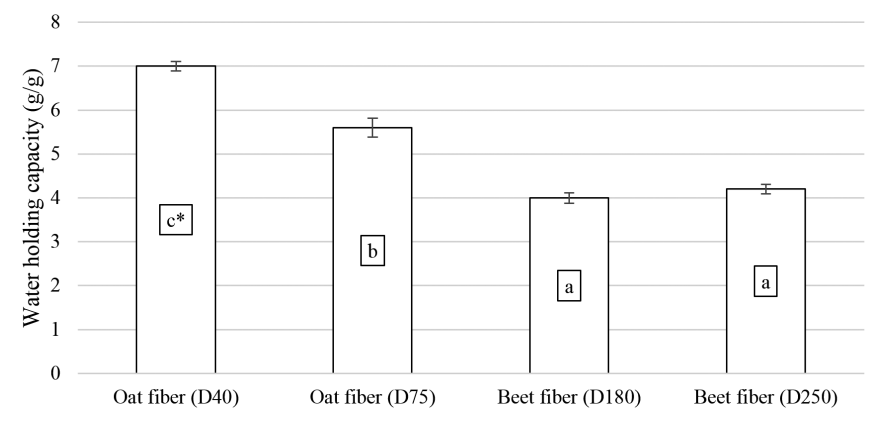

Figure 1. Water holding capacity (WHC) for different dietary fibers in g/g. *a, b, c- values with different letters differ significantly $(\mathrm{p} \leq 0.05)$. 
by (Filipovic et al., 2007), where the water holding capacity of beet fiber was $6.2 \mathrm{~g} / \mathrm{g}$, a different value than the one obtained in this research.

As far as the water absorption capacity of oat fiber, different outcomes were obtained than those achieved by other authors (Hager et al., 2010) who reached the conclusion that decreasing the size of a particle leads to a reduction of hydration properties. The collected results coincide with the theory of (Chau et al., 2006) who stated that a decrease in fiber particle size results in larger exposition of hydrophilic groups associated with water absorption capacity.

However, the hydration properties of fibers of different particle sizes coming from different sources should not be compared, since not only the size, but also the chemical structure and shape are of significant importance in hydration of fiber. There are also difficulties in comparing fibers, since the analysis of dry mass content should be conducted in order to compare hydration properties to the collected value.

\subsection{Particle size and shape analysis}

Table 1 shows particle size distribution of oat fiber in dry and wet dispersion.

The results obtained for dry fiber particles are similar to those presented by other authors (Rosell et al., 2009). However, it should be mentioned that there was used particles analyzer based on laser diffraction, and their convergent findings are evidence that automated static image analysis allows the exact determination of the size of dry fiber particles in the form of powder. In order to determine the proper hydration properties of the dietary fiber, the particle shape distribution should be taken into consideration. The results of the shape measurements of dietary fiber particles are presented in Table 2.
On the basis of our conducted research, it was established that the shape of the particle is a vital parameter in describing the behavior of fiber while in contact with water. It was observed that oat fibers while being hydrated become less circular and that the water makes the particle more longitudinal in shape, causing an observable lengthening of the particle. Moreover, water makes the oat fiber particles straighter. This is associated with the phenomena of turgor pressure in plant cells, which generates the stress that leads to the expansion of plant cells (Kroeger et al., 2011). The correlation between the size and shape properties of oat dietary fiber can be seen in Table 3. One could say that the size of the particle is the parameter least correlated with WHC. The most correlated parameters are fiber straightness and total fiber length. This observation leads to the conclusion that the methods of drying the dietary fiber do not always break the cell walls, because after hydration the shape of fiber could be regenerated.

The Table 4 presents the particle size distribution of the beet fiber in dry and wet dispersion.

The beet fiber has been ground slightly in the rotor mill - the particle size has changed by $-29 \%$. However, the particle size during hydration was higher for the dietary fiber with smaller particle size in the dry state. The increase in hydration properties may be due to the shearing of the cell wall and the collapse of the matrix structure upon grinding due to an increase in the theoretical surface area and the total pore volume (Elleuch et al., 2014). Smaller particles will have higher packing density, although particle composition and structure will contribute to the overall distribution of water.

Table 5 shows the shape parameters of beet fibers. The observations are different for fibers of vegetable origin than they are for cereal fiber. Only the width of the fiber changes significantly after contact with water.

Table 1. Particle size distribution of oat fiber in dry and wet dispersion.

\begin{tabular}{|c|c|c|c|c|c|}
\hline & Diameter D[3.2] $(\mu \mathrm{m})$ & Diameter $\mathrm{D}[4.3](\mu \mathrm{m})$ & $\begin{array}{l}\text { Diameter D } \\
{[\mathrm{v}, 0.1](\mu \mathrm{m})}\end{array}$ & $\begin{array}{l}\text { Diameter D } \\
{[\mathrm{v}, 0.5](\mu \mathrm{m})}\end{array}$ & $\begin{array}{l}\text { Diameter D } \\
{[\mathrm{v}, 0.9](\mu \mathrm{m})}\end{array}$ \\
\hline Oat fiber (D40) & $27.18 \pm 1.75^{a \star}$ & $43.95 \pm 3.84^{\mathrm{b}}$ & $12.94 \pm 0.77^{b}$ & $37.71 \pm 3.63^{\mathrm{a}}$ & $83.50 \pm 8.14^{\mathrm{b}}$ \\
\hline Oat fiber (D75) & $35.34 \pm 5.39^{\mathrm{a}}$ & $76.76 \pm 1.70^{\mathrm{ab}}$ & $14.64 \pm 2.23^{\mathrm{ab}}$ & $56.29 \pm 8.58^{\mathrm{ab}}$ & $142.65 \pm 9.27^{\mathrm{ab}}$ \\
\hline $\begin{array}{l}\text { Hydrated oat fiber } \\
\text { (D40) }\end{array}$ & $65.56 \pm 3.82^{\mathrm{b}}$ & $118.75 \pm 3.04^{\mathrm{b}}$ & $29.44 \pm 3.1^{\mathrm{bc}}$ & $91.89 \pm 8.80^{\mathrm{bc}}$ & $219.95 \pm 9.14^{\mathrm{ab}}$ \\
\hline $\begin{array}{l}\text { Hydrated oat fiber } \\
\text { (D75) }\end{array}$ & $70.58 \pm 9.61^{\mathrm{b}}$ & $130.28 \pm 4.88^{\mathrm{b}}$ & $32.83 \pm 1.85^{c}$ & $104.95 \pm 12.97^{c}$ & $233.18 \pm 18.59^{\mathrm{ab}}$ \\
\hline
\end{tabular}

$* a, b, c$ values with different letters differ significantly $(\mathrm{p} \leq 0.05)$.

Table 2. The shape parameters of oat fibers in dry and wet dispersion.

\begin{tabular}{|c|c|c|c|c|c|}
\hline & Circularity & Elongation & Fiber Straightness & $\begin{array}{c}\text { Fiber Total } \\
\text { Length }(\mu \mathrm{m})\end{array}$ & Fiber Width $(\mu \mathrm{m})$ \\
\hline Oat fiber (D40) & $0.94 \pm 0.01^{a \star}$ & $0.28 \pm 0.03^{\mathrm{a}}$ & $0.92 \pm 0.13^{a}$ & $14.10 \pm 2.15^{\mathrm{a}}$ & $7.93 \pm 1.21^{\mathrm{a}}$ \\
\hline Oat fiber (D75) & $0.93 \pm 0.01^{\mathrm{a}}$ & $0.24 \pm 0.04^{\mathrm{a}}$ & $0.94 \pm 0.14^{\mathrm{a}}$ & $13.17 \pm 2.01^{\mathrm{a}}$ & $7.26 \pm 1.11^{\mathrm{ab}}$ \\
\hline $\begin{array}{l}\text { Hydrated oat fiber } \\
\text { (D40) }\end{array}$ & $0.79 \pm 0.08^{b}$ & $0.26 \pm 0.03^{\mathrm{a}}$ & $0.86 \pm 0.03^{\mathrm{a}}$ & $36.76 \pm 4.88^{c}$ & $6.51 \pm 1.60^{\mathrm{ab}}$ \\
\hline $\begin{array}{l}\text { Hydrated oat fiber } \\
\text { (D75) }\end{array}$ & $0.73 \pm 0.08^{\mathrm{b}}$ & $0.29 \pm 0.0^{4 a}$ & $0.85 \pm 0.02^{\mathrm{a}}$ & $29.07 \pm 1.50^{\mathrm{b}}$ & $4.64 \pm 1.53^{\mathrm{ab}}$ \\
\hline
\end{tabular}

\footnotetext{
$\star a, b, c$ values with different letters differ significantly $(\mathrm{p} \leq 0.05)$
} 
Table 3. The shape parameters of oat fibers correlated to the WHC.

\begin{tabular}{lccccccc}
\hline & Diameter D[3.2] & Diameter D[4.3] & Circularity & Elongation & $\begin{array}{c}\text { Fiber } \\
\text { Straightness }\end{array}$ & $\begin{array}{c}\text { Fiber Total } \\
\text { Length }\end{array}$ & Fiber Width \\
\hline Oat fiber (D40) & 0.727 & 0.108 & -0.943 & 0.878 & $-0.994^{*}$ & $0.996^{*}$ & -0.936 \\
Oat fiber (D75) & -0.426 & -0.393 & 0.718 & -0.706 & 0.806 & 0.444 & 0.774 \\
\hline$*$ significt
\end{tabular}

Table 4. Particle size distribution of the beet fiber in dry and wet dispersion.

\begin{tabular}{|c|c|c|c|c|c|}
\hline & Diameter $\mathrm{D}[3.2](\mu \mathrm{m})$ & Diameter $\mathrm{D}[4.3](\mu \mathrm{m})$ & $\begin{array}{l}\text { Diameter D } \\
{[\mathrm{v}, 0.1](\mu \mathrm{m})}\end{array}$ & $\begin{array}{l}\text { Diameter D } \\
{[\mathrm{v}, 0.5](\mu \mathrm{m})}\end{array}$ & $\begin{array}{l}\text { Diameter D } \\
{[\mathrm{v}, 0.9](\mu \mathrm{m})}\end{array}$ \\
\hline Beet fiber (D180) & $97.07 \pm 4.79^{\mathrm{ab} *}$ & $180.85 \pm 7.56^{\mathrm{ab}}$ & $48.25 \pm 7.35^{\mathrm{a}}$ & $154.58 \pm 23.56^{\mathrm{ab}}$ & $370.54 \pm 56.47^{\mathrm{a}}$ \\
\hline Beet fiber (D250) & $110.61 \pm 6.86^{\mathrm{a}}$ & $252.83 \pm 8.53^{\mathrm{a}}$ & $49.19 \pm 7.50^{\mathrm{a}}$ & $230.85 \pm 35.18^{\mathrm{a}}$ & $508.58 \pm 77.51^{\mathrm{a}}$ \\
\hline $\begin{array}{l}\text { Hydrated beet fiber } \\
\text { (D180) }\end{array}$ & $141.83 \pm 9.77^{b}$ & $332.58 \pm 57.10^{\mathrm{b}}$ & $74.25 \pm 5.70^{\mathrm{b}}$ & $351.58 \pm 83.24^{\mathrm{ab}}$ & $434.98 \pm 66.18^{a}$ \\
\hline $\begin{array}{l}\text { Hydrated beet fiber } \\
\text { (D250) }\end{array}$ & $144.05 \pm 5.45^{\mathrm{ab}}$ & $272.65 \pm 8.05^{\mathrm{ab}}$ & $76.65 \pm 6.1^{\mathrm{b}}$ & $273.08 \pm 5.11^{\mathrm{b}}$ & $437.60 \pm 8.85^{\mathrm{a}}$ \\
\hline
\end{tabular}

${ }_{* a, b}$ values with different letters differ significantly $(\mathrm{p} \leq 0.05)$.

Table 5. The shape parameters of beet fibers in dry and wet dispersion.

\begin{tabular}{|c|c|c|c|c|c|}
\hline & Circularity & Elongation & Fiber Straightness & $\begin{array}{l}\text { Fiber Total } \\
\text { Length }(\mu \mathrm{m})\end{array}$ & $\begin{array}{l}\text { Fiber Width } \\
(\mu \mathrm{m})\end{array}$ \\
\hline Beet fiber (D180) & $0.85 \pm 0.02^{a x}$ & $0.25 \pm 0.01^{\mathrm{a}}$ & $0.91 \pm 0.01^{\mathrm{a}}$ & $17.90 \pm 2.32^{\mathrm{a}}$ & $4.21 \pm 0.21^{\mathrm{a}}$ \\
\hline Beet fiber (D250) & $0.88 \pm 0.02^{\mathrm{a}}$ & $0.23 \pm 0.01^{\mathrm{a}}$ & $0.92 \pm 0.10^{\mathrm{a}}$ & $10.69 \pm 1.35^{\mathrm{a}}$ & $3.76 \pm 0.19^{\mathrm{a}}$ \\
\hline $\begin{array}{l}\text { Hydrated beet fiber } \\
\text { (D180) }\end{array}$ & $0.89 \pm 0.14^{\mathrm{a}}$ & $0.28 \pm 0.04^{\mathrm{a}}$ & $0.92 \pm 0.14^{\mathrm{a}}$ & $17.31 \pm 2.64^{\mathrm{a}}$ & $6.53 \pm 0.99^{\mathrm{b}}$ \\
\hline $\begin{array}{l}\text { Hydrated beet fiber } \\
\text { (D250) }\end{array}$ & $0.88 \pm 0.13^{\mathrm{a}}$ & $0.29 \pm 0.04^{\mathrm{a}}$ & $0.93 \pm 0.14^{\mathrm{a}}$ & $19.43 \pm 2.96 \mathrm{~b}^{\mathrm{a}}$ & $7.61 \pm 1.16^{\mathrm{b}}$ \\
\hline
\end{tabular}

${ }^{\star a, b}$ values with different letters differ significantly $(\mathrm{p} \leq 0.05)$.

The correlation between the size and shape properties of the beet dietary fiber are presented in the Table 6 . As shown in case of the oat dietary fiber, the WHC and particle size are only slightly correlated. The most correlated particle characteristic for the beet fiber is fiber width. This observation leads to the conclusion that after contact with water beet fiber does not regenerate to the original fiber shape, instead forming a circular shape. The parameters are difficult to compare with those of other authors due to the lack of information about the shape of fiber treated with laser diffraction methods in the creation of various measurements.

Many authors criticize the method of doing particle analysis with the aid of laser diffraction, which has some flaws (Stojanović et al., 2012; Di Stefano et al., 2010). The following issues are raised, making it impossible to identify laser diffraction as an optimal way to measure hydration properties of dietary fiber. There is no other method to describe the shape of particles - especially if they are hydrated - than automated static image analysis. Stojanović et al. (2012) attempt to create a method for proper dispersion of samples in wet environments for laser diffraction. This method is, however, very cumbersome and time-consuming, requiring certain knowledge about optic properties, surface properties, phase composition and solubility of examined substances.

\subsection{Modeling and verification}

After having the matrix of result there was decided to make the model which could describe the WHC to investigate if it is possible the measure this parameter just after a set of automated static image analysis measurements on the dry sample. Firstly, we developed the model for the oat (Equation 1) and beet fiber (Equation 2) which could describe the dependence of WHC from size and shape of dietary fiber particle. We presented them below:

$$
\begin{aligned}
& \text { OatWHC }(\%)=6.18-0.80 A-8.71 B^{*} 10^{-6}+ \\
& 6.39 C^{*} 10^{-5}+4.35 D^{*} 10^{-5}-1.87 E^{*} 10^{-5}+2.9 F^{*} 10^{-6} \\
& \text { Beet } W H C(\%)=4.15+0.18 A+6.60 B * 10^{-17}+ \\
& 6.94 C^{*} 10^{-17}+6.85 D^{*} 10^{-17}+6.94 E^{*} 10^{-17}+6.56 F^{*} 10^{-1}
\end{aligned}
$$

We randomly take the oat and beet fiber to the automated static image analysis and the results of the measured parameters are presented in the Table 7.

The results that we achieved from the model were insignificantly different from the WHC measured conventionally. WHC for oat fiber was calculated as $6.05 \%$ and the conventional method gave the results $6.08 \%$. WHC for beet fiber was calculated $4.04 \%$ and measured $4.07 \%$. This lack of differences between the calculated values of WHC and measured ones showed that the automated static image analysis could be used as a tool for prediction of 
Table 6. The shape parameters of beet fibers correlated to the WHC.

\begin{tabular}{|c|c|c|c|c|c|c|c|}
\hline & Diameter D[3.2] & Diameter D[4.3] & Circularity & Elongation & $\begin{array}{c}\text { Fiber } \\
\text { Straightness }\end{array}$ & $\begin{array}{l}\text { Fiber Total } \\
\text { Length }\end{array}$ & Fiber Width \\
\hline $\begin{array}{l}\text { Beet fiber } \\
\text { (D180) }\end{array}$ & 0.916 & -0.447 & 0.238 & -0.281 & 0.012 & 0.167 & $0.987^{*}$ \\
\hline $\begin{array}{l}\text { Beet fiber } \\
\text { (D250) }\end{array}$ & 0.150 & -0.032 & 0.116 & -0.242 & -0.273 & 0.182 & $0.743^{*}$ \\
\hline
\end{tabular}

* significant correlation.

Table 7. The size and shape parameters of oat and beet fibers used in the verification procedure.

\begin{tabular}{lcccccc}
\hline & $\begin{array}{c}\text { Diameter D [4.3] } \\
(\mu \mathrm{m})\end{array}$ & Circularity & Elongation & Fiber Straightness & $\begin{array}{c}\text { Fiber Total Length } \\
(\mu \mathrm{m})\end{array}$ & Fiber Width $(\mu \mathrm{m})$ \\
\hline Oat & $60.25^{*}$ & 0.945 & 0.265 & 0.935 & 13.635 & 7.595 \\
Beet & 192.12 & 0.875 & 0.242 & 0.915 & 14.295 & 3.985 \\
\hline * significant correlation & & & & &
\end{tabular}

${ }^{*}$ significant correlation.

WHC without need to conduct the long taking conventional measurements.

\section{Conclusion}

Preparations of dietary fiber currently available on the market are diverse as far as their hydration properties. However, they may be divided into specific groups that show similar properties, such as fiber derived from grain processing. Conventional measurements of hydration properties of dietary fibers provide general measurements for the whole mass undergoing analysis. However, they make it impossible to learn about the behavior of given fiber and the changes in their shape and size during contact with water. A modern research tool, i.e. automated static image analysis on a microscopic scale, makes it possible to measure precisely the size and shape of particles in both dry and hydrated states. Due to the increasing interest of the scientific and industrial communities in the application of micronized fiber preparations, there seems to be justification for the creation of a new approach to research of particles that is not marked with the errors seen in the widely used method of particle size analysis using laser diffraction. The presented model could be easily transformed to WHC measurements instead of conducting the conventional time-consuming method.

\section{Acknowledgements}

The study was carried out under the purview of project no. POIG. 01.03.01-14-041/12 "Bioproducts", innovative technologies of pro-health bakery products and pasta with reduced caloric value co-financed by the European Regional Development Fund under the Innovative Economy Operational Programme 2007-2013.

\section{References}

Ahmed, J., Al-Jassar, S., \& Thomas, L. (2015). A comparison in rheological, thermal, and structural properties between Indian Basmati and Egyptian Giza rice flour dispersions as influenced by particle size. Food Hydrocolloids, 48, 72-83. http://dx.doi.org/10.1016/j. foodhyd.2015.02.012.
Autio, K., Flander, L., Kinnunen, A., \& Heinonen, R. (2001). Bread quality relationship with rheological measurements of wheat flour dough. Cereal Chemistry Journal, 78(6), 654-657. http://dx.doi. org/10.1094/CCHEM.2001.78.6.654.

Chau, C., Wen, Y., \& Wang, Y. (2006). Effects of micronisation on the characteristics and physicochemical properties of insoluble fibres. Journal of the Science of Food and Agriculture, 86(14), 2380-2386. http://dx.doi.org/10.1002/jsfa.2628.

Cloetens, L., Ulmius, M., Johansson-Persson, A., Akesson, B., \& Onning, G. (2012). Role of dietary beta-glucans in the prevention of the metabolic syndrome. Nutrition Reviews, 70(8), 444-458. http:// dx.doi.org/10.1111/j.1753-4887.2012.00494.x. PMid:22835138.

Di Stefano, C., Ferro, V., \& Mirabile, S. (2010). Comparison between grain-size analyses using laser diffraction and sedimentation methods. Biosystems Engineering, 106(2), 205-215. http://dx.doi. org/10.1016/j.biosystemseng.2010.03.013.

Elleuch, M., Bedigian, D., Maazoun, B., Besbes, S., Blecker, C., \& Attia, H. (2014). Improving halva quality with dietary fibres of sesame seed coats and date pulp, enriched with emulsifier. Food Chemistry, 145, 765-771. http://dx.doi.org/10.1016/j.foodchem.2013.08.085. PMid:24128542.

Elleuch, M., Bedigian, D., Roiseux, O., Besbes, S., Blecker, C., \& Attia, H. (2011). Dietary fibre and fibre-rich by-products of food processing: characterisation, technological functionality and commercial applications: A review. Food Chemistry, 124(2), 411-421. http:// dx.doi.org/10.1016/j.foodchem.2010.06.077.

Filipovic, N., Djuric, M., \& Gyura, J. (2007). The effect of the type and quantity of sugar-beet fibers on bread characteristics. Journal of Food Engineering, 78(3), 1047-1053. http://dx.doi.org/10.1016/j. jfoodeng.2005.12.050.

Hager, A.-S., Ryan, L. M., Schwab, C., Gänzle, M. G., O’Doherty, J. V., \& Arendt, E. K. (2010). Influence of the soluble fibres inulin and oat $\beta$-glucan on quality of dough and bread. European Food Research and Technology, 232(3), 405-413. http://dx.doi.org/10.1007/ s00217-010-1409-1.

Huang, C. C., Chen, Y. F., \& Wang, C. C. R. (2010). Effects of micronization on the physico-chemical properties of peels of three root and tuber crops. Journal of the Science of Food and Agriculture, 90(5), 759-763. http://dx.doi.org/10.1002/jsfa.3879. PMid:20355109.

Kroeger, J. H., Zerzour, R., \& Geitmann, A. (2011). Regulator or driving force? The role of turgor pressure in oscillatory plant cell 
growth. PLoS One, 6(4), e18549. http://dx.doi.org/10.1371/journal. pone.0018549. PMid:21541026.

Kurek, M., Wyrwisz J., Piwińska, M., \& Wierzbicka, A. (2015). Application of the response surface methodology in optimizing oat fiber particle size and flour replacement in wheat bread rolls. CyTA - Journal of Food, 1-9. http://dx.doi.org/10.1080/19476337.2015.1036309.

Ma, Z., Merkus, H. G., de Smet, J. G. A. E., Heffels, C., \& Scarlett, B. (2000). New developments in particle characterization by laser diffraction: size and shape. Powder Technology, 111(1-2), 66-78. http://dx.doi.org/10.1016/S0032-5910(00)00242-4.

Melanson, K. J., Angelopoulos, T. J., Nguyen, V. T., Martini, M., Zukley, L., Lowndes, J., Dube, T. J., Fiutem, J. J., Yount, B. W., \& Rippe, J. M. (2006). Consumption of whole-grain cereals during weight loss: effects on dietary quality, dietary fiber, magnesium, vitamin B-6, and obesity. Journal of the American Dietetic Association, 106(9), 13801388, quiz 1389-1390. http://dx.doi.org/10.1016/j.jada.2006.06.003. PMid:16963343.

Noort, M. W. J., van Haaster, D., Hemery, Y., Schols, H., \& Hamer, R. J. (2010). The effect of particle size of wheat bran fractions on bread quality - Evidence for fibre-protein interactions. Journal of Cereal Science, 52(1), 59-64. http://dx.doi.org/10.1016/j.jcs.2010.03.003.
Ozen, A. E., Pons, A., \& Tur, J. A. (2012). Worldwide consumption of functional foods: a systematic review. Nutrition Reviews, 70(8), 472-481. http://dx.doi.org/10.1111/j.1753-4887.2012.00492.x. PMid:22835140.

Rosell, C. M., Santos, E., \& Collar, C. (2009). Physico-chemical properties of commercial fibres from different sources: a comparative approach. Food Research International, 42(1), 176-184. http://dx.doi. org/10.1016/j.foodres.2008.10.003.

Stojanović, Z., Marković, S., \& Uskoković D. (2012). Determination of particle size distributions by laser diffraction. Technics - New Materials, 67, 11-20.

Vissotto, F. Z., Giarola, R. C., Jorge, L. C., Makita, G. T., Cardozo, G. M. B. Q., Rodrigues, M. I., \& Menegalli, F. C. (2014). Morphological characterization with image analysis of cocoa beverage powder agglomerated with steam. Food Science and Technology, 34(4), 649-656.

Zhu, K., Huang, S., Peng, W., Qian, H., \& Zhou, H. (2010). Effect of ultrafine grinding on hydration and antioxidant properties of wheat bran dietary fiber. Food Research International, 43(4), 943-948. http:// dx.doi.org/10.1016/j.foodres.2010.01.005. 